\title{
ON THE INFLUENCE OF HAPPINESS ON HUMAN HEALTH
}

In Happiness And Contemporary Society : Conference Proceedings Volume (Lviv, March, 20-21, 2021). Lviv: SPOLOM, 2021. P. 182-186. https://doi.org/10.31108/7.2021.42

ISBN 978-966-919-697-2

\section{ДО ПИТАННЯ ВПЛИВУ ЩАСТЯ НА ЗДОРОВ'Я ЛЮДИНИ}

// Щастя та сучасне суспільство : збірник матеріалів міжнародної наукової конференції (Львів, 20-21 березня 2021 р.). - Львів : СПОЛОМ, 2021. С. 182-186. https://doi.org/10.31108/7.2021.42

ISBN 978-966-919-697-2 


\author{
MARTSENIUK Maryna \\ Ph.D in Psychology, Senior Lecturer \\ Mukachevo State University (Mukachevo, Ukraine)
}

\title{
ON THE INFLUENCE OF HAPPINESS ON HUMAN HEALTH
}

The article considers the concept and phenomen on of happiness from the perspective of different authors. The subjective perception and interpretation of the term happiness and the vital interest in this phenomen on by such sciences as philosophy, ethics, psychology, history, medicine. The concept of happiness in a narrow (fate, talent, luck, success, joy) and broad (psycho-emotional state of complete satisfaction with life, a sense of complete joy) senses has been covered.

The ratings of the countries on the level of happiness among population (WorldHappinessReport) and the «happiness index» studied by the international foundation NEF (NewEconomicsFoundation) have been analyzed, along with the position of Ukraine.

The finding soft helongest-running study from Harvard University, which aimed to find out what makes people happy from adolescence to old age, have been presented. It has been found that good relationships with people make us happier and healthier. Good social connections are good for us, but loneliness shortens life. It was proved that the happiest of the participants in the experiment, even feeling physicalpain, stayed positive. In stead, un happy people feltthat the physical pain became even stronger dueto a bad emotional state. The importance of a spouse supporting, and its positive impact on such a process as memory was emphasized. Instead, it was noted that their memory did not deteriorate as rapidly as in single people.

Key words: health, life satisfaction, feelings of happiness, level of happiness.

$$
\begin{gathered}
\text { МАРЦЕНЮК Марина } \\
\text { старший викладач кафедри психологї МДУ } \\
\text { Мукачівський державний університет (м.Мукачево, Украӥна) }
\end{gathered}
$$

\section{ДО ПИТАННЯ ВПЛИВУ ЩАСТЯ НА ЗДОРОВ'Я ЛЮДИНИ}

Щорічно 20 березня, у світі відзначають Міжнародний день щастя. Рішення про відзначення цього дня прийняла Генеральна Асамблея ООН на своєму 118-му пленарному засіданні. На офіційну думку $\mathrm{OOH}$, сприяння процесам сталого розвитку, справедливості та викорінення злиднів, більш комплексного та збалансованого підходу до економічного зростання, активне сприяння благополуччю всіх народів, невід'ємно стосується питань забезпечення щастя як для окремої особистості, так і для суспільства в цілому.

Що ж таке «щастя» цікавило людство ще з часів древньогрецьких філософів. Сьогодні вивченням поняття щастя займаються різні науки: філософія, етика, психологія, історія, і навіть медицина. Однак чіткого визначення щастя немає, адже кожен розуміє його по-своєму. У найширшому розумінні щастя - 
психоемоційний стан цілковитого задоволення життям, відчуття повної радості. На думку американського психолога-гуманіста Абрахама Маслоу, сутністю щастя $\epsilon$ задоволення потреб людини: від фізіологічних (голод, спрага, сон) і до найвищої потреби у самореалізації. Отже, люди щасливі - це люди самореалізовані. А фізіологами встановлено, що за стан щастя відповідає кора лівої префронтальної ділянки головного мозку, а загальновідомими «гормонами щастя» є: ендорфіни, серотонін, дофамін [2].

Згідно словника, щастя - це «стан цілковитого задоволення життям, відчуття глибокого вдоволення і безмежної радості, яких зазнає хто-небудь; досягнення, успіх, удача», а також «доля, талан» [4].

Відомий дослідник щастя М.Аргайл вважає, що «..щастя, яке частіше за все визначається як переживання радості», - це єдиний фактор людського досвіду, однак воно складається по меншій мірі з трьох, частково незалежних факторів: задоволеності життям, позитивних емоцій і відчутності негативних емоцій», причому радість - це емоційна сторона щастя, а задоволеність - когнітивна, «це рефлексивна оцінка, судження про те, наскільки все було i залишається благополучним» [1].

У широкому сенсі щастя - це емоційний стан (емоція), за якого людина відчуває внутрішню задоволеність умовами свого існування, повноту й осмисленість життя і здійснення свого призначення; усвідомлення позитивності контексту власного існування. Існує думка, щастя є ціннісною категорією, що відображає задоволеність бажаним; безмежну радість буття.

Загалом, психологічне визначення досліджуваного феномену пов'язане 3 розумінням його як відчуття повноти буття, радості та задоволеності життям, що лежать в основі оптимального, здорового й ефективного функціонування особистості.

Синонімами терміну «щастя» $\epsilon$ : велика радість чи задоволення, благополуччя, благодать, блаженство, задоволеність життям, насолода, вдача.

Важливо зазначити, що до 60 -х років XX ст. порушена проблематика перебувала поза увагою наукової психології. Ї̈̈ систематичне дослідження у психологічній науці почалося в останні десятиліття, передусім у гуманістичній i позитивній психології (А.Маслоу) та вчення про сенс життя В. Франкла.

Одним 3 аргументів на користь виокремлення позитивної психології як дисципліни була необхідність розгортання власне психологічних досліджень щастя. Позитивна психологія зі свого зародження наприкінці минулого століття поставила за мету вивчити шляхи і можливості досягнення людиною хорошого та гідного життя, процвітання (М. Аргайл, Е. Дінер, Д. Майерс, М. Селігман, М. Чиксентмихалі та ін.). Головним у позитивній психології було питання операціоналізації та вимірювання щастя. Після тривалих дискусій за умовну міру щастя було прийнято характеристику «суб'єктивного благополуччя», пов'язану із задоволеністю життям і позитивними емоціями. Для вимірювання щастя були створені такі методики як: «Шкала задоволеності життям» Дінера, «Оксфордський опитувальник щастя» М.Аргайла, «Шкала щастя» Фордіса, «Афективний баланс» Брендберна й інші [3].

Вперше опис портрету щасливої людини зробив К. Роджерс. Дослідник виділив декілька умов «щасливого життя», під яким розумів не статичний, а 
динамічний процес. До таких умов належить те, що: щасливі люди прагнуть жити теперішнім; довіряють не авторитетам та ідеям, а власним почуттям та інтуїції; щасливі люди завдяки своєму творчому підходу до життя здатні легко пристосовуватися до умов, які постійно змінюються [9].

Відомий класик психології Карл Юнг виділяв п'ять найголовніших складових людського щастя. На його думку, саме ці складові повністю задовільнять потреби середньостатистичної людини:

1. Хороше фізичне та психологічне здоров'я, оскільки задовільний стан людини вже сам по собі викликає почуття задоволеності.

2. Хороші відносини з друзями та сім'єю.

3. Здатність до сприймання краси. Стосується це краси природи та мистецтва.

4. Задоволеність своєю професією.

5. Філософська або релігійна точка зору, яка допоможе впоратись 3 різноманітними проблемами, також допоможе бути щасливішим [8].

Окремі аспекти щастя висвітлювалися у різних наукових напрямах та багаточисельних роботах науковців, у тому числі: історичні передумови становлення ідей про щастя як про самореалізацію людини (Конфуцій, Аристотель, Епікур, Я. А. Коменський та інші); суть феномену щастя з погляду сучасної філософії (Р. Айдинян, І. Сидоренко, В. Татаркевич та інші), етики (А. Гусейнов, К. Нешев, В. Шепель та інші), психології (М. Аргайл, І. Джидар'ян, Б. Додонов, О. Леонтьєв, В.А.Пертровський, А.З.Шапіро та інші), педагогіки (В. Глассер, О. Павлова, В. Сухомлинський, Н. Щуркова та інші).

Найвідоміший рейтинг країн світу за рівнем щастя населення (WorldHappinessReport) складається під егідою ООН в рамках глобальної ініціативи «Мережа рішень сталого розвитку» і враховує понад 30 показників, таких як валовий внутрішній продукт на душу населення, очікувана тривалість життя, соціальна підтримка, сприйняття корупції, привабливість країни для іммігрантів та багато інших. Україна за 2018 й рік зайняла 138-е місце в рейтингу зі 156 країн світу. Лідирують в рейтингу найщасливіших країн Фінляндія, Норвегія, Ісландія, Швейцарія, Нідерланди, Канада, Нова Зеландія, Швеція та Австралія [5].

Натомість за даними «індексу щастя», який вивчає міжнародна фундація NEF (NewEconomicsFoundation) на основі суб'єктивної оцінки благополуччя, рівня здоров'я та екологічного стану оточуючого середовища перші місця найщасливіших країн займають: Коста-Рика, В’єтнам, Колумбія, Беліз, Сальвадор, Ямайка, Панама, Гватемала. Щоправда, Україна в цьому рейтингу також розташована наприкінці першої сотні [6].

Попри усі проблеми і негаразди, більшість жителів України не втрачають оптимізму. Згідно опитування, яке проводив Київський міжнародний інститут соціології (КМІС) у травні 2018 року щасливими або скоріше щасливими себе відчували 63\% мешканці України, 16\% почувалися частково щасливими, частково ні, і 17\% - нещасливими. Порівняно із 2017 роком, частка щасливих українців збільшилася на $10 \%$ [2].

Грунтуючись на результатах наведених досліджень, можна зазначити, що відчуття щастя залежить від багатьох чинників, у тому числі соціально- 
демографічних ознак. Молоді люди загалом щасливіші, аніж старші. В Україні 3 віком рівень щастя знижується майже лінійно, зниження частки щасливих із віком пов'язане із погіршенням здоров'я, а також більш хистким матеріальним становищем і самотністю, які часто спіткають літніх людей. Чим вищий рівень добробуту, тим більше людей почуваються щасливими. Так, за даними Київського міжнародного інституту соціології, серед найбідніших щасливими себе назвали $40 \%$, серед малозабезпечених таких $58 \%$, серед людей із середнім доходом - $74 \%$. Стан здоров'я є дуже важливою умовою для відчуття щастя: серед тих, хто має дуже хороше здоров'я, щасливими почуваються $88 \%$, серед тих, хто має дуже погане здоров'я, щасливими є лише $18 \%$.

Вважаємо за потрібне, навести цікаві висновки найтривалішого дослідження Гарвардського університету, яке було покликане з'ясувати, що робить людей щасливими з підліткового і до літнього віку. Дослідження розпочалось у 1938 році й триває досі, впродовж цих років у 724 респондентів щорічно запитували про їхнє здоров'я, особисте життя, роботу. Цікаво, що 60 його учасників ще живі i продовжують брати участь в цьому експерименті. За свідченням професора Р.Волдінгера - четвертого керівника експерименту, найважливіший результат 3 цього понад 75-річного дослідження полягає в наступному: хороші стосунки 3 людьми роблять нас щасливішими і здоровішими. Добрі соціальні зв'язки корисні для нас, а ось самотність скорочує життя. Ті учасники експерименту, які мали сім'ї, друзів, хороші контакти в суспільстві, щасливіші, фізично здоровіші і живуть довше, аніж ті, у кого таких соціальних зв'язку було мало. При цьому важливими $\epsilon$ не лише наявність багатьох друзів чи партнера у шлюбі, але й якість цих близьких стосунків.

Відповідно до вищезазначеного дослідження Гарвардського університету, що найщасливіші з учасників експерименту у 80-річному віці зізнавались, що навіть коли вони відчували фізичний біль, їх не покидало відчуття щастя. Тоді як ті, хто почував себе нещасливим, відчували, що фізичний біль ставав ще сильнішим через поганий емоційний стан. Пам'ять залишалась кращою у тих, хто міг розраховувати на свого подружнього партнера. Навіть якщо пара часто сварилась, але відчувала, що кожен може розраховувати один на одного у складних ситуаціях, для їхнього мозку це було терапевтично - пам'ять не погіршувалась так швидко, як у самотніх людей [7].

Висновок. Тлумачення феномену щастя (суб' єктивного благополуччя) не позбавлене різночитань. Навіть ті, хто згідний, що щастя - це задоволеність життям, можуть коливатися між різними інтерпретаціями цієї задоволеності конкретної й абстрактної, об'єктивної і суб'єктивної, реальної й ідеальної, широкої та вузької.

Щастя як дослідницька категорія є міждисциплінарним феноменом. Існує велика філософська, психологічна, літературознавча, культурологічна, соціологічна, богословська бібліографія, присвячена щастю та його пошукам питання що таке щастя людське, як досягти щастя, належать до числа «вічних» питань. Вони хвилювали людину ще в сиву давнину, що відобразилося в народних повір'ях, приказках та прислів'ях на кшталт: «кожен сам коваль свого щастя».

Поняття «щастя» фіксує ступінь вдоволення індивіда від реалізації життєвих цілей, оцінку досягнутого в порівнянні з високим ідеалом. 


\section{ЛITEPATУРА}

1. Аргайл М. Психология счастья / М. Аргайл. - М. : Прогресс, 1990. - 336 с.

2. Відчуття щастя позитивно впливає на стан фізичного здоров'я Режим доступу: https://www.medcv.gov.ua/archives/21549

3. Життєві домагання особистості: колективна монографія / [Титаренко Т. М., Лебединська І. В., Алікіна Н. В. та ін.]. - К.: "Педагогічна думка", 2007. - 453 с.

4. Щастя // Словник української мови: в 11 тт. / АН УРСР. Інститут мовознавства; за ред. І. К. Білодіда. - Т.11. - К.: Наукова думка, 1980. - С. 573.

5. Рейтинг країн світу за рівнем щастя. Режим доступу: https://www.bbc.com/ukrainian/news-47635260

6. Міжнародний індекс щастя. Режим доступу: https://uk.wikipedia.org/wiki/Мiжнародний індекс щастя.

7. Що робить нас щасливими? Режим доступу: https://life.pravda.com.ua/society/2016/01/4/205921/.

8. Интервью Гордона Янга: К.Г. Юнг. Искусство жить. Режим доступу до pecypcy: https://castalia.ru/perewody/karl-gustav-yung-perevody/2627-albertozriyung-govorit-kg-yung-intervyu-gordonu-yangu-iskusstvo-zhit-1960.html.

9. Переверзєва А. В. Індекс людського щастя - показник рівня реалізації людського потенціалу. Режим доступу: http://base.dnsgb.com.ua/files/journal/Aktualni-problemy-ekonomiky /Aktprobekonomiky-2009-7/Akt-prob-ekonomiky-2009-7_201-207.pdf. 